\title{
Evaluation of the food safety management system in a hospital food service operation toward Listeria monocytogenes
}

\author{
E. Lahou*, L. Jacxsens, E. Verbunt, M. Uyttendaele \\ University of Ghent, Department of Food Safety and Food Quality, Laboratory of Food Microbiology and Food Preservation, Coupure Links, 653, 9000 Ghent, \\ Belgium
}

\section{A R T I C L E I N F O}

\section{Article history:}

Received 17 September 2012

Received in revised form

18 September 2013

Accepted 13 October 2013

Available online 1 November 2013

\section{Keywords:}

Risk-based sampling plan

Food safety management system

Hospital food service operation

Listeria monocytogenes

\begin{abstract}
A B S T R A C T
The unique aspects of a hospital environment, such as the multitude of dietary needs and thus the variety of meals to be served and incoming (raw) materials to be used, challenge the development and application of appropriate control and assurance measures to guarantee food safety. Besides, Listeria monocytogenes is considered a risk for most food service operations producing and serving ready-to-eat foods. Therefore the food safety management system of a hospital food service operation has been evaluated toward L. monocytogenes with an extensive questionnaire in the preset of this case study. In addition, 49 samples of food products and 145 environmental samples were taken and analyzed for $L$. monocytogenes to verify the implemented control measures. From this case study, it becomes clear that incoming (raw) materials, produced final products and their immediate supply to patients/consumers are high risk situations. This was demonstrated by the presence of L. monocytogenes in six incoming (raw) materials $(n=19)$ and one final product $(n=9)$. These risky situations are in need to be mitigated by the implementation of proper control measures, e.g. intensified supplier control, low storage temperatures, cleaning and disinfection to control cross-contamination. However major improvements can be made on the hygienic design of equipment and facilities and on the level of the sampling design. In terms of assurance activities, such as setting up a sampling plan, only a basic level was obtained for the validation and verification of their food safety management system. This case study illustrates that the combination of data from the questionnaire together with data of the sampling result in an overview on the performance of the current food safety management system and that major non-compliances and possibilities for improvement in the system can be defined.
\end{abstract}

(ㄷ) 2013 Elsevier Ltd. All rights reserved.

\section{Introduction}

The foodborne pathogen Listeria monocytogenes is the causative agent of listeriosis, a severe disease with high hospitalization rates and mortality rates ranging from 16 to 30\% (Cairns \& Payne, 2009; Denny \& McLauchin, 2008; EFSA, 2009, 2010, 2011, 2012; Gandhi \& Chikindas, 2007). The FAO/WHO reported yearly incidence rates of 0.3-7.5 cases per million people in Europe (FAO/WHO, 2004). Although rates of listeriosis have remained stable, a changing pattern of human listeriosis can be observed in Europe (EFSA, 2009, 2010, 2011, 2012; Gillespie et al., 2006; Goulet, Hedberg, Le Monnier, \& de Valk, 2008). Listeriosis is now affecting the elderly ( $>65$ years) population more often and pregnant women less

\footnotetext{
* Corresponding author. Tel.: +32 09 2649390; fax: +32 092255510

E-mail address: evy.lahou@ugent.be (E. Lahou).
}

frequently (Metelmann, Schulz, Geldschläger-Canda, Plötz, \& Handrick, 2010; Muñoz et al., 2011). It has been shown that the majority of these elderly persons are suffering from underlying diseases and therefore most listeriosis infections are occurring in immune-compromised elderly persons, which form part of the hospital population (FAO/WHO, 2004; Gillespie, Mook, Little, Grant, \& Adak, 2010; Muñoz et al., 2011). Moreover, such vulnerable persons are more likely than healthy individuals to be affected by low numbers of a pathogen and are more likely to suffer severe consequences of infection (Lianou \& Sofos, 2007; Lund \& O'Brien, 2009).

Lund and O'Brien (2009) summarize in their review foodborne L. monocytogenes outbreaks in health care settings between 1997 and 2008. From these data it can be concluded that hospitals were involved in six outbreaks of $L$. monocytogenes infection and that cases could be linked to consumption of ready-to-eat (RTE) foods. Surveillance and epidemiological data also revealed an association 
between food handling at retail and food service establishments and the incidence of foodborne illness (Lianou \& Sofos, 2007). However, no studies about the prevalence of $L$. monocytogenes in food handling areas of hospital food service operations were retrieved, although data on the distribution and transmission of L. monocytogenes in hospital food-processing environments and retail can be found in literature (Hoelzer et al., 2011; Lund \& O'Brien, 2009; Rodriguez et al., 2011). These and other studies on the potential transmission of $L$. monocytogenes within retail and food service operations revealed that the potential sources of the organism include the environment (utensils and equipment), food handlers and incoming raw or processed products that have been contaminated after a lethal treatment at the manufacturing facility (Lianou \& Sofos, 2007; Tompkin, 2002). Besides, high prevalence data of $L$. monocytogenes in RTE products and on food contact surfaces at retail and commercial food service operations can be found (Hoelzer et al., 2011; Lianou \& Sofos, 2007).

This necessitates the implementation of appropriate control and assurance measures to prevent foodborne outbreaks within a hospital. However, this is challenged by the unique aspects of retail and food service operations, such as variety of meals to be served and incoming (raw) materials to be used. Therefore, the purpose of this study was to evaluate the current implemented control and assurance activities toward L. monocytogenes within a hospital food service operation. This was performed using an extensive questionnaire, which can be used as a self-assessment tool, combined with additional samples of incoming (raw)materials, meal components, final products and (non-)food contact surfaces. The combination of the data from the questionnaire together with the data of the sampling, results in an overview on the efforts taken to prevent $L$. monocytogenes (re)contamination, reveals major noncompliances and defines possibilities for improvement in the food safety management system.

\section{Materials and methods}

\subsection{Characterization of the hospital food service operation}

A Belgian hospital food service operation with approximately 120 employees has been selected for the case study. This hospital is inspected and certified for its legally demanded self-checking system, based on good practices and HACCP, according to EU Regulation 852/2004 (Anonymous, 2004) and relevant Belgian legislation (Anonymous, 2003). Meals are prepared and cooked in the on-site hospital kitchen and distributed directly to the patients under responsibility of the nursing staff or are served in the hospital canteen which is accessible for patients, visitors and staff. The hospital food service operation is working with two production lines. One production line, referred to as "hot kitchen", is used to produce hot meals from raw materials, ingredients or cooked half-fabricates. Another production line, referred to as "cold kitchen", is used to produce cold meals such as salads and sandwiches. The hot kitchen, where food handlers start with processing raw materials (e.g. frying of the meat, cooking of vegetables), is the most important production line producing approximately 1200 hot meals/day. As soon as the food is prepared, it is kept at temperatures of $>65^{\circ} \mathrm{C}$ in hot water baths until lunch time. Just before serving time all food handlers are involved in composing the meal on a plate, thus with risk of post-contamination, according to dietary needs of patients. Final composed meals are then collected in preheated trolleys to transport them to the patients. The cold kitchen processes (e.g. cutting of vegetables) and assembles raw vegetables and ready-toeat products (e.g. smoked salmon) into salads or sandwiches which are mainly served in the hospital canteen. In total approximately 2600 meals are produced each day consisting of 600 patient breakfasts, 700 hot patient meals, 500 hot canteen meals, 700 patient dinners (mainly cold meals) and 100 cold canteen meals.

\section{2. (Self-)assessment questionnaire}

The objective of the questionnaire is to analyze and asses a selected number of major food safety management activities to get a broad and overall impression on the efforts taken to prevent, in this case study, L. monocytogenes (re)contamination. Therefore the context in which the hospital food service operates and which puts demands on the food safety management system, the level of implemented core assurance and core control activities of the food safety management, and the microbiological system performance which is the output of a food safety management system (Fig. 1) were assessed with the (self-)assessment questionnaire which is composed of lists of indicators (Table 1) (Jacxsens et al., 2010). The (self-)assessment questionnaire was developed for food processing companies by Jacxsens et al. (2010) and Luning, Bango, Kussaga, Rovira, and Marcelis (2008, 2009, 2011a) but have been slightly adapted for its use in (hospital) food service operations. The modified indicators for food service operations are indicated with an asterisk in Table 1. The situations/levels of the different indicators were assessed with an on-site visit and a $3 \mathrm{~h}$ face-to-face interview with the HACCP-coordinator of the hospital food service operation.

\subsubsection{Structure of (self-)assessment questionnaire}

The questionnaire is subdivided into a part with context indicators to assess the situation in which the hospital food service is operating, a part with activity indicators to assess the currently implemented core assurance and core control measures and a part with microbiological system performance indicators for assessing the output of the food safety management in place (Fig. 1). The context has been defined as a condition, characteristic or situation which is a given fact or cannot be easily changed on the short term, but which can influence the performance of the food safety management system. Contextual factors include product, process, organizational and chain environmental characteristics. Core control and assurance activities form the actual food safety management system where assurance activities such as setting system requirements, validation, verification,... have the aim to provide evidence and confidence to stakeholders. Control activities are activities that create circumstances to prevent entry and/or growth of pathogens in food production systems (preventive measures design), activities that inactivate or eliminate pathogens in order to reduce them to acceptable levels (intervention process design), activities that measure (critical) product or process parameters

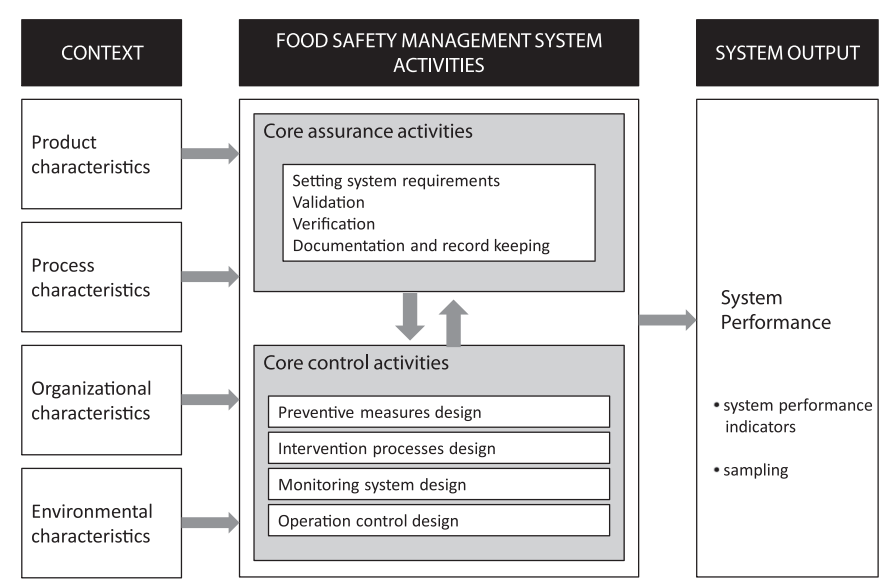

Fig. 1. Structure and relationship between the groups of the (self-)assessment questionnaire. 
Table 1

Results of the (self-)assessment questionnaire.

\begin{tabular}{|c|c|c|c|}
\hline & Indicator & $\begin{array}{l}\text { Situation } \\
\text { level }^{\mathrm{a}}\end{array}$ & Motivation \\
\hline \multirow[t]{15}{*}{ Context factors } & Risk of raw material & High risk & $\begin{array}{l}\text { High diversity, main products (e.g. raw meat, fresh vegetables) } \\
\text { may carry pathogens and have a high initial microbial load. }\end{array}$ \\
\hline & Risk of meals* & High risk & $\begin{array}{l}\text { Produced meals are sensitive to pathogen growth as a result of } \\
\text { intrinsic properties of the products and are prone to post- } \\
\text { contamination. }\end{array}$ \\
\hline & Intervention steps & Moderate risk & $\begin{array}{l}\text { The production processes contain intervention steps (e.g. } \\
\text { cooking) to inactivate vegetative cells, but spores can still } \\
\text { survive and recontamination can still occur after the lethal } \\
\text { intervention step (e.g. when assembling meals). }\end{array}$ \\
\hline & Assortment of meals* & Moderate risk & $\begin{array}{l}\text { Only a restricted number of recipes are prepared (Max. three } \\
\text { "hot" daily menus) which allows in-between cleaning and } \\
\text { disinfection interventions }\end{array}$ \\
\hline & Rate of menu changes* & Moderate risk & $\begin{array}{l}\text { Repeating menu cycle of } 4 \text { weeks allows less product and } \\
\text { process modifications. }\end{array}$ \\
\hline & Technological staff & Moderate risk & HACCP-team of six persons is available. \\
\hline & Variability in workforce composition & Low risk & Low turnover of employees, no temporary operators. \\
\hline & Operator competences & Low risk & $\begin{array}{l}\text { Chefs have professional education level in cuisine, employees } \\
\text { attend specific food safety training on recruitment. }\end{array}$ \\
\hline & Management commitment & Low risk & $\begin{array}{l}\text { Food service operation has detailed written vision statement on } \\
\text { safety and has official quality team. }\end{array}$ \\
\hline & Employee involvement & Low risk & $\begin{array}{l}\text { Employees are involved in the design and modifications of the } \\
\text { food safety management system (e.g. notification of problems, } \\
\text { ideas on improvement) }\end{array}$ \\
\hline & Formalization & Low risk & $\begin{array}{l}\text { Standard operational procedures and documentation are } \\
\text { available for employees. }\end{array}$ \\
\hline & Information systems & High risk & $\begin{array}{l}\text { Temperatures are recorded manually by staff, information is } \\
\text { limited available and not accurate to take food safety control } \\
\text { decisions. }\end{array}$ \\
\hline & Safety contribution in chain position & High risk & $\begin{array}{l}\text { Direct serving of meals to "susceptible" group, thus it has a } \\
\text { critical position with respect to reduction and/or inactivation of } \\
\text { pathogens to acceptable levels. }\end{array}$ \\
\hline & Power in supplier relationships & Low risk & $\begin{array}{l}\text { Discussion on product specifications possible, perform audits at } \\
\text { new suppliers. }\end{array}$ \\
\hline & Strictness of stakeholders requirements & Low risk & $\begin{array}{l}\text { General legislative requirements on food safety, execute self } \\
\text { assessment. }\end{array}$ \\
\hline \multirow[t]{15}{*}{ Core control activities } & $\begin{array}{l}\text { Hygienic design of equipment and } \\
\text { facilities }\end{array}$ & Basic & $\begin{array}{l}\text { Equipment and facilities are not well designed to prevent } \\
\text { contamination and pathogens entrance (e.g. no strict separation } \\
\text { of preparation rooms). }\end{array}$ \\
\hline & Cooling facilities & Advanced & $\begin{array}{l}\text { Presence of industrial cooling facilities adapted for food service } \\
\text { food production which are automatically controlled }\left(<4^{\circ} \mathrm{C}\right) \text {. }\end{array}$ \\
\hline & Sanitation programs & Advanced & $\begin{array}{l}\text { Presence of complete full-step cleaning procedure with pre- } \\
\text { cleaning, cleaning, disinfection and in-between rinsing with } \\
\text { instructions and use of specific cleaning agents. }\end{array}$ \\
\hline & Personnel hygiene requirements & Advanced & $\begin{array}{l}\text { Specific requirements on clothing for all employees, personnel } \\
\text { care and health and tailored facilities to support personnel } \\
\text { hygiene. }\end{array}$ \\
\hline & Raw material control & Advanced & $\begin{array}{l}\text { Incoming materials are systematically checked based on actual } \\
\text { data of suppliers and quality is visually assessed at entrance. }\end{array}$ \\
\hline & Meal preservation* & Not applicable & Meals are not stored. \\
\hline & Defrosting methods* & Advanced & $\begin{array}{l}\text { Based on legislative requirement and guidance documents, } \\
\text { method has been tested. }\end{array}$ \\
\hline & Hot-holding methods* & Advanced & $\begin{array}{l}\text { Based on legislative requirement and guidance documents, } \\
\text { method is tested daily. }\end{array}$ \\
\hline & Physical intervention equipment & Advanced & $\begin{array}{l}\text { The present intervention equipment (steam ovens, cooking } \\
\text { pots, frying pans) are adequate for the production process } \\
\text { (different programs available) and capability is tested by } \\
\text { monitoring of core temperatures }\left(\geq 70^{\circ} \mathrm{C}\right) \text {. }\end{array}$ \\
\hline & $\begin{array}{l}\text { Maintenance and calibration program } \\
\text { for equipment }\end{array}$ & Generic & $\begin{array}{l}\text { Structural program is present with specific instructions about } \\
\text { frequency and maintenance tasks but is not specifically } \\
\text { designed for process. }\end{array}$ \\
\hline & Effectiveness of intervention methods & Advanced & $\begin{array}{l}\text { Intervention equipment is tested by measuring core } \\
\text { temperatures of prepared food products. }\end{array}$ \\
\hline & CCP analysis & Generic & $\begin{array}{l}\text { Based on hygiene codes for sector according to official Codex } \\
\text { guidelines, but are not tested. }\end{array}$ \\
\hline & Standards and tolerances design & Advanced & $\begin{array}{l}\text { Standards and tolerances are scientifically underpinned, comply } \\
\text { with legislative requirements. }\end{array}$ \\
\hline & Analytical methods to assess pathogens & Advanced & $\begin{array}{l}\text { Analytical methods used by lab are internationally validated } \\
\text { and accreditated methods. }\end{array}$ \\
\hline & $\begin{array}{l}\text { Measuring equipment to monitor } \\
\text { process/product status }\end{array}$ & Generic & $\begin{array}{l}\text { Standard available measurement equipment complying with } \\
\text { ISO norms, on-line/in-line measurement (e.g. probes in steam } \\
\text { ovens). }\end{array}$ \\
\hline
\end{tabular}


Table 1 (continued)

\begin{tabular}{|c|c|c|c|}
\hline & Indicator & $\begin{array}{l}\text { Situation } \\
\text { level }^{\mathrm{b}}\end{array}$ & Motivation \\
\hline & $\begin{array}{l}\text { Calibration program for measuring } \\
\text { equipment }\end{array}$ & & $\begin{array}{l}\text { Calibration program with tasks and frequencies which are in- } \\
\text { house documented. }\end{array}$ \\
\hline & Sampling design & Basic & $\begin{array}{l}\text { No own samples are taken, in case of new supplier samples are } \\
\text { taken from the raw materials, once a year external control by } \\
\text { government. }\end{array}$ \\
\hline & Corrective actions & Advanced & $\begin{array}{l}\text { Presence of complete descriptions on what to do in case product } \\
\text { and/or process parameters exceed tolerances or limits. }\end{array}$ \\
\hline & Actual availability of procedures & Generic & $\begin{array}{l}\text { General working instructions are available on the workplace but } \\
\text { are paper-based. }\end{array}$ \\
\hline & Actual compliance to procedures & Generic & $\begin{array}{l}\text { Majority of employees are familiar with existence of } \\
\text { procedures, tasks are executed based on habits. }\end{array}$ \\
\hline & $\begin{array}{l}\text { Actual hygienic performance of } \\
\text { equipment/facilities }\end{array}$ & Advanced & $\begin{array}{l}\text { Stable hygiene performance of equipment and facilities based } \\
\text { on data of executed tests (two times/year external control with } \\
\text { rodac and swabs, every three months ATP-measurement } \\
\text { themselves). }\end{array}$ \\
\hline & Actual cooling capacity & Advanced & $\begin{array}{l}\text { Stable performance of cooling facilities }\left(<4^{\circ} \mathrm{C}\right) \text {, temperature is } \\
\text { automatically monitored, alarm when temperature deviates. }\end{array}$ \\
\hline & Actual hot-holding capacity* & Advanced & $\begin{array}{l}\text { Stable performance of hot-holding facilities }\left(>80^{\circ} \mathrm{C}\right) \\
\text { temperature is systematically monitored. }\end{array}$ \\
\hline & $\begin{array}{l}\text { Actual process capability of } \\
\text { intervention processes }\end{array}$ & Advanced & $\begin{array}{l}\text { Stable process, core temperatures of the food are measured with } \\
\text { probes and intervention process is adjusted. }\end{array}$ \\
\hline & $\begin{array}{l}\text { Actual performance of measuring } \\
\text { equipment }\end{array}$ & Generic & $\begin{array}{l}\text { Measuring equipment is sensitive for a few specific well known } \\
\text { meal production changes. }\end{array}$ \\
\hline \multirow[t]{9}{*}{ Core assurance activities } & $\begin{array}{l}\text { Translation of stakeholder } \\
\text { requirements }\end{array}$ & Generic & $\begin{array}{l}\text { Systematic translation of stakeholder requirements into own } \\
\text { food safety management system. }\end{array}$ \\
\hline & $\begin{array}{l}\text { Systematic use of feedback information } \\
\text { to modify system }\end{array}$ & Advanced & $\begin{array}{l}\text { HACCP-team evaluates feedback information from validation } \\
\text { and verification reports. }\end{array}$ \\
\hline & Validation of preventive measures & Basic & $\begin{array}{l}\text { Effectiveness of preventive measures is ad hoc judged by own } \\
\text { HACCP-team. }\end{array}$ \\
\hline & Validation of intervention systems & Basic & $\begin{array}{l}\text { Effectiveness of intervention processes is ad hoc judged by own } \\
\text { HACCP-team. }\end{array}$ \\
\hline & Validation of monitoring systems & Basic & $\begin{array}{l}\text { Effectiveness of monitoring system is ad hoc judged by own } \\
\text { HACCP-team. }\end{array}$ \\
\hline & $\begin{array}{l}\text { Verification of people related } \\
\text { performance }\end{array}$ & Basic & $\begin{array}{l}\text { No internal audit is executed to check if the compliance to } \\
\text { procedures are operating in practice. }\end{array}$ \\
\hline & $\begin{array}{l}\text { Verification of equipment and methods } \\
\text { related performance }\end{array}$ & Generic & $\begin{array}{l}\text { Analyzing records data loggers on a regular basis, but no } \\
\text { confirmation by actual testing. }\end{array}$ \\
\hline & Documentation & Generic & $\begin{array}{l}\text { Structured kept-to-date documentation system, but only } \\
\text { available for authorized persons. }\end{array}$ \\
\hline & Record keeping system & Generic & $\begin{array}{l}\text { Full registration of critical product and process data but only } \\
\text { accessible for authorized persons. }\end{array}$ \\
\hline \multirow[t]{7}{*}{ System performance output } & $\begin{array}{l}\text { Evaluation of food safety management } \\
\text { system }\end{array}$ & Poor & $\begin{array}{l}\text { No own evaluation of the system, rely on the yearly inspection } \\
\text { of the national food safety agency. }\end{array}$ \\
\hline & Severity of complaints & Good & No complaints or remarks from the national food safety agency. \\
\hline & Food safety complaints & Good & No complaints concerning microbial food safety. \\
\hline & Hygiene complaints & Good & No complaints concerning microbial hygiene indicators. \\
\hline & Product sampling & Poor & Only ad hoc sampling of raw materials and end products. \\
\hline & Assessment criteria & Moderate & $\begin{array}{l}\text { Use only legal criteria and requirements, no own specifications } \\
\text { defined. }\end{array}$ \\
\hline & $\begin{array}{l}\text { Non-conformities regarding food } \\
\text { hygiene and pathogens }\end{array}$ & Moderate & $\begin{array}{l}\text { Only a few non-conformities regarding one specific problem } \\
\text { (e.g. hand hygiene). }\end{array}$ \\
\hline
\end{tabular}

\footnotetext{
* specific indicator for food service operations.

a in case of context factors.

b in case of core control activities, core assurance activities and system performance output.
}

(monitoring system design) and activities that concerns the way the activities are operating in practice (operation control strategies) and have the aim of keeping product properties, production processes and human processes between certain acceptable tolerances. The system output was assessed in the questionnaire with system performance indicators to provide an indication of the current status of the functionality of the implemented food safety management system, i.e. what is the expected quality and safety of the meals produced in the hospital food service operation and how is their food safety management system currently evaluated by third parties.

\subsubsection{Indicators of the (self-)assessment questionnaire}

The list of indicators used in the questionnaire is shown in Table 1 . The questionnaire comprises 15 context indicators, 34 activity indicators and 7 system performance indicators. Each context indicator (Fig. 2A) has a grid with descriptions of three contextual situations (low, moderate and high risk) to assess the risk type of the food service operation. A more risky context will put higher demands on the food safety management system e.g. incoming (raw) materials with potential presence of pathogens will demand cooling conditions, more severe supplier selection and also a strict follow up during processing. Each activity indicator (Fig. 2B) has a grid with descriptions of four different levels (not applicable, basic, generic and advanced) of performance where an activity level will be classified as basic when the activity is based on companies own information and history and when general working methodology is applied. A generic level is assigned when the activity is based on 'best practices' or 'best present technology' and is based on generic sector information. An advanced level will be assigned if 
A. Example of a context indicator

In which of the following situations would you place the risk of the meals in your kitchen?

Risk of meals

Assumption: Meals which are susceptible to pathogen growth or toxin formation (due to the intrinsic product properties and or applied inactivation technique), increase the chance on lower food safety performance, and put higher demands on the food safety management system by requiring advanced control and assurance activities.

\begin{tabular}{|c|c|c|}
\hline Situation 1 (low risk) & Situation 2 (moderate risk) & Situation 3 (high risk) \\
\hline $\begin{array}{l}\text { Major meals are } \\
\text { microbiologically stable }\left(\mathrm{a}_{\mathrm{w}}\right. \\
<0.6 \text { or } \mathrm{pH}<4.2 \text { or contains } \\
\text { intrinsic antimicrobial agents). } \\
\text { A complete inactivation of the } \\
\text { flora takes place and post- } \\
\text { contamination is not likely. The } \\
\text { meals can be served as } \\
\text { bought and do not require } \\
\text { handling before service. }\end{array}$ & $\begin{array}{l}\text { The meals have following } \\
\text { characteristics: } 0.98>\mathrm{a}_{\mathrm{w}}>0.6 \text { or } 4.2<\mathrm{pH} \\
<6.5 \text { or contains no antimicrobials). } \\
\text { Contamination of meals is not likely to } \\
\text { occur. The meals are cooked/reheated } \\
\text { and then immediately served. }\end{array}$ & $\begin{array}{l}\text { The meals have following } \\
\text { characteristics: } \mathrm{a}_{\mathrm{w}}>0.98 \text { or } \mathrm{pH} 6.5- \\
7.5 \text { or contains no antimicrobials). } \\
\text { Contamination of meals can occur } \\
\text { (no inactivation of original flora or } \\
\text { post-contamination). The meals are } \\
\text { fresh-type meals or hot-held meals. }\end{array}$ \\
\hline
\end{tabular}

B. Example of an activity indicator.

At which level would you place the method regarding the hot-holding of the meals in your kitchen?

\section{Hot-holding methods}

Assumption: Adequate hot holding methods better maintain strict temperature conditions to prevent growth of micro-organisms and pathogens, which will positively contribute to food safety.

\begin{tabular}{|l|l|l|l|}
\hline $\begin{array}{l}\text { Level } \mathbf{0} \text { (not } \\
\text { applicable) }\end{array}$ & Level 1 (basic) & Level 2 (generic) & Level 3 (advanced) \\
\hline $\begin{array}{l}\text { Hot-holding of meals } \\
\text { kitchen. }\end{array}$ & $\begin{array}{l}\text { Hot-holding method is based } \\
\text { on company knowledge/ } \\
\text { experience and has not been } \\
\text { tested on effectiveness for } \\
\text { kitchens 'specific food } \\
\text { production system. }\end{array}$ & $\begin{array}{l}\text { Hot-holding method is } \\
\text { based on sector } \\
\text { guidelines, legislative } \\
\text { requirements and/ or } \\
\text { expert knowledge, but has } \\
\text { not been tested on } \\
\text { effectiveness for } \\
\text { kitchens' specific food } \\
\text { production system. }\end{array}$ & $\begin{array}{l}\text { Hot-holding method is } \\
\text { based on legislative } \\
\text { requirements/ guidance } \\
\text { documents but adapted } \\
\text { for own production } \\
\text { process and tested on } \\
\text { effectiveness for kitchens' } \\
\text { specific food production } \\
\text { system. Actual product } \\
\text { temperature is checked } \\
\text { for different } \\
\text { circumstances. }\end{array}$ \\
& & &
\end{tabular}

C. Example of a system performance indicator

At which level would you place the customers' complaints regarding microbiological food safety?

Food safety complaints

Assumption: The presence of a good functioning system for complain registration and evaluation is an important aspect in the food safety management system. Low number of complaints regarding microbiological food safety of final products and hygiene indicates a good system performance. When complaints can be dedicated to one specific aspect of the food safety management system or one type of pathogen/hygiene indicator, a well performing food safety management system and a good system performance can be expected.

\begin{tabular}{|l|l|l|l|}
\hline Level 0 (absent) & Level 1 (poor) & Level 2 (moderate) & Level 3 (good) \\
$\begin{array}{l}\text { No indication of } \\
\text { system performance } \\
\text { because complaints } \\
\text { are not registered. }\end{array}$ & $\begin{array}{l}\text { Various complaints that can } \\
\text { be traced back to several } \\
\text { problems of the operation of } \\
\text { the food safety management } \\
\text { system. }\end{array}$ & $\begin{array}{l}\text { A limited number of } \\
\text { complaints that can be } \\
\text { traced back to one specific } \\
\text { problem with the } \\
\text { functioning of the food } \\
\text { safety management } \\
\text { system }\end{array}$ & $\begin{array}{l}\text { No complaints on the } \\
\text { microbiological safety of } \\
\text { the meals. }\end{array}$ \\
\end{tabular}

Fig. 2. Example of an indicator for the context (A), an activity (B) and system performance (C) as used in the (self-)assessment questionnaire.

the activity is based on scientific knowledge, adequate information and tailored to the specific situation of the food service operation. Each system performance indicator (Fig. 2C) has a grid with descriptions of four different levels (absent, poor, moderate and good) of microbiological performance. The HACCP-coordinator had to assign for each indicator which level or situation was most representative for his food service operation.

\subsubsection{Interpretation of the (self-)assessment questionnaire}

The indicators of the assessment will create a profile of the food safety management system. In case of context indicators, a more risky contextual situation is expected to result more easily in food safety problems, and therefore higher demands will be put on the food safety management system. In case of activity indicators, a higher/more sophisticated level of control and assurance activities 
means that the food service operation has a more advanced food safety management system in place, and can control their microbiological food safety output better. In case of the system performance indicators, a better system performance means that the likelihood of food safety problems is reduced.

\subsection{Sampling plan}

Sampling of incoming high risk (raw) materials, meal components, final products and (non-)food contact surfaces was performed to verify supplier selection and implemented control measures toward L. monocytogenes. Microbiological analyses cannot assure food safety on its own, but can be used to evaluate whether a food safety management system is providing the control it was designed to deliver. Sampling was executed three times in a three month period (January-March 2011). In total 145 environmental samples and 49 food samples were analyzed.

\subsubsection{Identification of at risk foods and critical sampling locations}

Because the range of incoming (raw) materials in the food service operation is broad and not all food products are a risk in terms of presence of $L$. monocytogenes, an identification of at risk products was elaborated to select those incoming (raw) materials of interest to be taken up in the sampling plan. Incoming (raw) materials were therefore classified into food types with similar microbiological ecology toward L. monocytogenes based upon the type of commodity and prior processing or preservation method applied (Lahou, Jacxsens, Daleman, Van Landeghem, \& Uyttendaele, 2012). These food types were then screened for i) the reported epidemiological association of the food type with listeriosis outbreaks, ii) the reported prevalence of $L$. monocytogenes in the food types, and iii) the potential of $L$. monocytogenes to grow or survive during storage and/or further processing to identify high risk products. This screening was performed with a literature study carried out in ICMSF books (ICMSF, 1986, 2002, 2005) complemented with the Community Summary Reports on Trends and Sources of zoonoses of the European Food Safety Authority (EFSA, 2006, 2007, 2009, 2010, 2011, 2012). To verify the general EU situation for the regional situation, the Annual Reports on Zoonotic agents in Belgium of the Federal Agency for the Safety of the Food Chain (FASFC) and the Belgian Report on Zoonoses and Zoonotic agents were consulted (Dierick \& Botteldoorn, 2007; Dierick, Bottledoorn, Denayer, \& Naranjo, 2009; FAVV, 2004, 2006b, 2007, 2008b, 2009a,b).

Critical sampling locations were identified by analyzing the flow chart of the production process. Possible sites of crosscontamination or post-contamination, such as utensils, slicing machines, hands of food handlers and plates were taken up in the sampling plan. Non-food contact surfaces, such as drains, ventilation, vans, trolleys, door handles, wheels and conveyer belts were selected on the basis of information from literature and reports about the distribution and transmission of L. monocytogenes in food service operations and retail (Hoelzer et al., 2011; Lianou \& Sofos, 2007; Lund \& O’Brien, 2009; Rodriguez et al., 2011).

\subsubsection{Elaboration of the risk based sampling plan}

The attribution of a risk level to the defined incoming (raw) material food types and the identification of critical sampling locations was the basis for selection of incoming (raw) materials and environmental samples to be taken up in the sampling plan. The daily menus of the food service operation were obtained from the HACCP coordinator a week prior to the visit and were screened for high risk ingredients. A total of 49 food and 145 environmental samples were collected during three visits on three days at various critical sampling locations (CSL) in the process from raw material to final food product. For food products, $100 \mathrm{~g}$ was aseptically collected with a sterile spoon or forceps and transferred to a sterile sampling bag. Food contact surfaces, hands and gloves were swabbed in a delimited area of $100 \mathrm{~cm}^{2}$ using a sterile Quantiswab ${ }^{\circledR}$ (Biomérieux) premoistened in neutralizing solution. The food samples and the moistened swabs were transported in a cool box at $4{ }^{\circ} \mathrm{C}$ to the laboratory where microbiological analyses to detect L. monocytogenes were performed within $6 \mathrm{~h}$ of sample collection. The moistened swabs were enriched with $225 \mathrm{ml}$ demi-fraser for $24 \mathrm{~h}$ at $30^{\circ} \mathrm{C}$, followed by transferring $0.1 \mathrm{ml}$ enrichment to $10 \mathrm{ml}$ fraser broth. After incubation for $24 \mathrm{~h}$ at $37^{\circ} \mathrm{C}, 0.5 \mathrm{ml}$ was transferred to a VIDAS LMO2 strip (BioMérieux) which was analyzed for presence of $L$. monocytogenes (AFNOR n ${ }^{\circ} \mathrm{BIO}-12 / 11-03 / 04$ ). Detection of $L$. monocytogenes was performed on $25 \mathrm{~g}$ food product also according Vidas LMO2 (BioMérieux), an AFNOR validated enzymelinked fluorescent assay (ELFA) (AFNOR ${ }^{\circ}$ BIO-12/11-03/04). When positive results were obtained, $L$. monocytogenes was enumerated from the food sample according to ISO 11290-2:1998/Amd 1:2004 (plating on ALOA and incubation of $48 \mathrm{~h}$ at $37^{\circ} \mathrm{C}$ ).

\section{Results}

\section{1. (Self-)assessment questionnaire}

\subsubsection{Context factors}

Table 1 lists the results of the (self-)assessment questionnaire. Important contextual factors which influence the food safety management system in this food service operation belong to product and production process characteristics. The high diversity of incoming (raw) materials used in the hospital food service operation (e.g. raw meat, raw fish, smoked fish, ready-to-eat vegetables and fruits, cooked meat) and the high microbial load of the products (e.g. $10^{6} \mathrm{CFU} / \mathrm{g}$ on raw meat and poultry), which may also contain pathogens such as Salmonella spp. and L. monocytogenes, contribute to a high risk situation (Jacxsens et al., 2011; Luning, Jacxsens et al., 2011; Uyttendaele, Jacxsens, De Loy-Hendrickx, Devlieghere, Debevere, 2010). The produced meals were classified as a high risk situation because they are sensitive to pathogen growth as a result of the intrinsic properties of the products and are prone to post-contamination. The organizational characteristics, which give insight in the ability to prevent safety problems, and the chain environment characteristics, which refer to the position of the food service operation in the food chain and its relationship with stakeholders such as suppliers and controlling bodies, are in this food service operation in general at lower risk for the food safety management performance. However, the information system wherein information, knowledge and data should be systematically recorded to support decisions on food safety and quality issues was not accurate to take food safety control decisions and was recorded manually which results in a high risk situation. As a hospital food service operation is situated in the last part of the food supply chain and is serving meals to a "susceptible" group, it has a critical position with respect to reduction and/or inactivation of pathogens. Therefore the indicator "safety contribution in chain position" has been classified as a high risk situation.

\subsubsection{Core control activities}

Control activities concern the ongoing process of evaluating performance of both technological and human processes and taking corrective actions when necessary. It is assumed for control activities that a better activity level is better able to keep product properties, production processes and human processes between certain acceptable tolerances (Luning et al., 2008). Core control activities are in general well implemented in the food safety management system of the food service operation (Table 1). 
Table 2

Overview of analyzed samples and number of positive Listeria monocytogenes samples.

\begin{tabular}{|c|c|c|c|c|}
\hline & 1st visit & 2nd visit & 3rd visit & Total \\
\hline $\begin{array}{l}\text { Raw materials } \\
\text { (raw meat, raw fish, smoked fish, sandwich spread, ready-to-eat vegetables and fruits, cooked meat) }\end{array}$ & $3 / 8$ & $1 / 6$ & $2 / 5$ & $6 / 19^{\mathrm{a}}$ \\
\hline $\begin{array}{l}\text { Meal components } \\
\text { (fried meat, cooked fish, milkshake, sliced vegetables, tuna spread) }\end{array}$ & $0 / 6$ & $0 / 9$ & $0 / 6$ & $0 / 21$ \\
\hline $\begin{array}{l}\text { Composed meal (final product) } \\
\text { (Ardennes egg, Veal stew with hot vegetables and potatoes, Meat escalope with hot vegetables and rice, } \\
\text { fresh mixed fruit meal }(3 \mathrm{x}) \text {, tuna salad, chicken salad, meat loaf with hot vegetables and potatoes, } \\
\text { tomato salsa) }\end{array}$ & $1 / 3$ & $0 / 3$ & $0 / 3$ & $1 / 9^{\mathrm{a}}$ \\
\hline \multicolumn{5}{|l|}{ Environment } \\
\hline $\begin{array}{l}\text { Direct } \\
\text { (food containers, utensils, slicing machine, plates, cooking kettle, food } \\
\text { handlers hands) }\end{array}$ & $0 / 33$ & $0 / 30$ & $0 / 24$ & $0 / 87$ \\
\hline $\begin{array}{l}\text { Indirect } \\
\text { (ventilation refrigerator, floor drains, trolley, door handle, walls, conveyer belt, wheels, hood, dishwasher } \\
\text { belt, plateau) }\end{array}$ & $0 / 18$ & $0 / 20$ & $0 / 20$ & $0 / 58$ \\
\hline Total & $4 / 68$ & $1 / 68$ & $2 / 58$ & $7 / 194^{\mathrm{a}}$ \\
\hline
\end{tabular}

${ }^{\text {a }}$ Listeria monocytogenes is present in $25 \mathrm{~g}$ but $<100 \mathrm{CFU} / \mathrm{g}$.

However, a basic level was assigned to the hygienic design of equipment and facilities, which means that equipment and facilities are not well designed to prevent (cross-)contamination and entrance of pathogens. More specific, there is no strict separation between the different preparation areas within the food service operation. Contamination of products or parts of the environment increases the risk to contaminate other products and other parts of the area. A basic level was also assigned to the sampling design because samples are only taken from incoming materials supplied by new suppliers and no information is available on the distribution of pathogens in the food service operation as they take no specific (environmental) samples.

\subsubsection{Core assurance activities}

Core assurance activities are activities that provide evidence and confidence to stakeholders that safety requirements will be met. It is assumed for assurance activities that a better activity level is better able to provide confidence that safety requirements will be met because better requirements are set on the system, its performance is better evaluated and changes are better organized (Luning et al., 2009). From Table 1 it can be derived that the core assurance activities are performing on a basic to a generic level. A basic level was assigned to the validation of preventive measures, intervention systems and monitoring systems because its effectiveness is only ad hoc judged by their own HACCP-team instead of being validated independently. The verification of people related performance, checking whether requirements on people related activities (i.e. compliance to procedures) are operating in practice as designed, was also assigned a basic level because no verification of the procedures is executed and compliance is based on checking their presence by dependent persons.

\subsubsection{System performance indicators}

The system performance indicators provide more information about the output of the food safety management system. It is assumed that a better level is associated with a better system performance which means that the likelihood of food safety problems is reduced (Jacxsens et al., 2010). As noticed in Table 1, the evaluation of food safety management system is poor because the food service operation performs no self-evaluation of the food safety management system e.g. via internal auditing. Besides it only relies on data from the yearly inspection of the national food safety agency to judge their food safety management system. Product sampling is also poor because there is only ad hoc sampling of incoming (raw) materials in case of a new supplier and ad hoc sampling of end products on demand of third parties, e.g. the government.

\subsection{Risk based sampling plan}

The sampled high risk incoming (raw) materials for L. monocytogenes in the food service operation and their results are presented in Table 2. These raw materials were also sampled at critical sampling locations along their production process where, besides the food product, samples were taken from the direct (food contact surfaces such as utensils, slicers, plates) and indirect (nonfood contact surfaces such as ventilations, floor drains, door handlers, trolleys, conveyer belts) environment. L. monocytogenes could be detected (in $25 \mathrm{~g}$ ) in $3.61 \%$ of the samples $(=194)$. L. monocytogenes was detected in six incoming (raw) material samples $(n=19)$, namely salt-free cooked ham, raw meat sandwich spread, raw salmon, smoked salmon $(2 \times)$ and raw poultry meat, and in one final product $(n=9)$, namely the Ardennes egg which consist out of salt-free cooked ham, lettuce, tomatoes, carrots, cooked egg and mayonnaise. However, enumeration of the positive samples revealed that the concentration of the pathogen was $<100 \mathrm{CFU} / \mathrm{g}$. No L. monocytogenes was detected in any of the 145 environmental samples.

\section{Discussion}

The principle behind the (self-)assessment questionnaire is that a food service operation operating in a more vulnerable (to safety problems), uncertain (due to the lack of information), ambiguous (due to the lack of insight in underlying mechanisms) and unpredictable situation, which can be seen as a high-risk context, requires control and assurance activities at a more advanced level (Luning, Marcelis et al., 2011). In this case study, a high risk context was posed by the high diversity of (raw) ingredients entering the food service operation. Therefore, well controlled storage conditions, proper supplier selection and a good follow up during further interventions processes are required to deal with this microbial risk and thus higher demands are posed on the food safety management system (Jacxsens et al., 2011; Luning, Jacxsens et al., 2011). A high risk context was also posed by the variability of the produced meals and the high risk position of the food service operation due to serving meals directly to the patient/consumer. These risky situations were largely compensated by the requirement of specific competences for employees and by low personnel turn-over and the absence of part-time workers, which decrease the chance of poor execution of tasks. However, food service operations commonly have a relatively high turn-over of personnel or temporary staff, which may complicate the development of a regular training program and cause problems with poor handling practices, 
or would require stronger management to ensure that staff adhere to food safety controls (Jones \& Angulo, 2006; Jones, Parry, O'Brien, \& Palmer et al., 2008; Worsfold, 2001) Besides, a higher staff turnover makes it more difficult to create a food safety culture, which is built on a set of shared values that operators and their staff follow to produce and provide food in the safest manner (Powell, Jacob, \& Chapman, 2011). In the current food service operation, employees are also involved in the design and modifications of the food safety management (e.g. notification of problems, ideas on improvement) which results in a higher commitment and motivation of the staff, lowering the risk context. Besides, standard operational procedures and documentation (assessed by the formalization indicator) were present which results in the absence of higher demands on the food safety management system (Luning, Marcelis et al., 2011). Moreover, the food service operation has the ability to discuss microbial specifications with their suppliers and to select the supplier with the best specifications. This ability of the food service operation to influence the quality and handling practices of the foods before they enter the hospital kitchen and thereby ensuring that supplies are obtained from high-quality suppliers and thereby reducing the likelihood of contaminated products entering the food service operation, contributes to a lower risk context (Jones et al., 2006; Lianou \& Sofos, 2007).

Core assurance activities were in general implemented on a basic level, which is often noticed in food service operations. The verification of people related performance, i.e. checking whether requirements on compliance to procedures are operating in practice as designed, is one of these activities which is executed on a basic level. This means that they only check if procedures are present, but no internal audits are performed to check the actual behavior of the food handlers and to assure that they work in compliance with procedures. However, researchers have suggested that the observation of food preparation practices and the assessment of food-handling practices of the employees through internal observations, external evaluations and inspections, contribute to a food safety culture which is one of the most effective measures to reduce rates of foodborne illness (Powell et al., 2011). Studies have shown that improper food handler practices (e.g. inadequate hand washing, wearing the same gloves for extended periods of time, handling unwrapped RTE meats after handling raw meats without washing hands) may result in cross-contamination of RTE foods and account for approximately 97 percent of foodborne illnesses (Green et al., 2006; Lianou \& Sofos, 2007; Neal, Binkely, \& Henroid, 2012). Therefore, performing observations on the behavior of food handlers and changing incorrect behavior can improve the level of this indicator leading to a more advanced food safety management system but will also contribute to the developing of a food safety culture (Luning et al., 2009). Nowadays, education and training are the focus of many food-handling behavior interventions, however these programs are often inconsistent and their knowledge evaluation is a poor indicator of changes in practices (Powell et al., 2011). Other core assurance activities, such as validation of preventive measures, validation of intervention processes and validation of the monitoring system, which are now performed on a basic level will become more advanced if the validation is based on scientific evidence and if it is systematic and independently performed (Luning, Marcelis et al., 2011). However, the validation, to assure that they work well, is currently based on historical knowledge judged by own people and only ad-hoc performed.

Core control activities, on the other hand, were implemented on a more advanced level. Especially their activities that create circumstances to prevent growth of pathogens in food production systems (preventive measures design), such as the adequacy of their cooling facilities, and their activities that inactivate or eliminate pathogens in order to reduce them to acceptable levels (intervention process design), such as the effectiveness of the intervention equipment, are well established. However, major improvements can be made on the level of the hygienic design of equipment and facilities and on the level of a sampling design. The facilities had no strict separation of preparation rooms which may facilitate crosscontamination because there is no forward flow with returns and crossing among raw materials, ready-to-eat meals and trash. The design of this food service operation was drawn in 1977 and it is difficult to change in the short-term. However, a shift in location of the food service operation took place in 2012. In this new production area, the hygienic design of the facility and equipment was adjusted to meet more modern standards regarding space efficiency, flexibility, product flow, food safety and ergonomics, which will improve the level of this indicator. Food service operations, however, are frequently of unhygienic design and crowded with staff and equipment to satisfy occasional workloads which makes it difficult to control basic sanitary standards resulting in an increased number of critical control points to prevent the risk of cross-contamination and recontamination of food (Panisello \& Quantick, 2001). In 2008 , the national agency for the safety of the food chain performed 12,492 inspections regarding the infrastructure, design and hygiene in food service operations. These inspections revealed that only $56 \%$ of the food service operations were in accordance with the criteria regarding the infrastructure, design and hygiene in food service operations (FAVV, 2009b). The adequacy of the sampling plan could also be improved to obtain a more advanced level. However, a sampling plan is not provided in the self-checking guide for the sector of food service operations and health care institutions (FAVV, 2006a, 2008a). Therefore the food service operation is not obliged to take own samples of final products. For these results the food service operation relies currently on the sampling of the national agency for the safety of the food chain which is performed in the frame of inspection, but this sampling is not frequently performed (once a year) and is rather limited. On the other hand, samples are taken from incoming (raw) materials in case of new suppliers to verify their specifications. Therefore, raw material control is performing on a more advanced level (Luning et al., 2008). Besides, selection of credible suppliers is based on raw material specifications and supplier audits, which reduces the likelihood of contaminated products entering the food service operation (Lianou \& Sofos, 2007; Luning et al., 2008). However, testing should be used to verify that risk-reduction measures are working as intended and therefore a sampling plan should be designed (Dufour, 2011; Powell et al., 2011). This would also increase the level of the core assurance activities by increasing the level of the indicator "verification of equipment and methods related performance".

In this case-study a risk based sampling plan was developed and elaborated to verify the control measures toward L. monocytogenes. Samples have been taken from incoming (raw) materials, meal components and final products as well from the environment, because environmental sources may, under conditions of poor cleaning and sanitation, harbor pathogenic micro-organisms such as $L$. monocytogenes or serve as vehicles for cross-contamination (Lianou \& Sofos, 2007). Especially, non-food contact surfaces, such as floor drains and cold floors, have a higher prevalence of $L$. monocytogenes in comparison with food contact surfaces such as slicers and utensils (Carpentier \& Cerf, 2011; Dimitrijevíc et al., 2011; Hoelzer et al., 2011). In this case study, the pathogen was not found in the environmental samples. However, a study of Hoelzer et al. (2011) revealed that in $58 \%(n=241)$ of retail deli establishments, $L$. monocytogenes isolates were found in the environment of the establishment. Therefore, cleaning and disinfection applied in this food service operation is efficient to remove biofilms of $L$. monocytogenes and to prevent an accumulation of high numbers of $L$. monocytogenes in the food production environment. However, recovery rates of swabs are low and therefore small 
amounts of the pathogen may be present in the food production environment but could not be detected (Hedin, Rynbäck, \& Loré, 2010; Moore \& Griffith, 2007). Incoming raw materials, namely raw salmon and raw poultry meat, and RTE products, such as smoked salmon, raw meat sandwich spread and cooked ham, have been testing positive (in $25 \mathrm{~g}$ ) for the presence of $L$. monocytogenes. A study of Uyttendaele et al. (2009) shows that the prevalence of $L$. monocytogenes for cooked meat is approximately $1.1 \%(n=639)$ and for smoked fish is approximately $27.8 \%(n=90)$. Van Coillie, Wrebrouck, Heyndrickx, Herman, and Rijpens (2004) detected a prevalence for $L$. monocytogenes in smoked salmon of $19 \%(n=42)$. This high prevalence of $L$. monocytogenes in fish products, may explain the finding of Listeria positive raw materials although a small number of samples has been taken. The cooked meat was salt-free because it was adapted to the dietary needs of the patients. However, the reduction of salt increases the survival of L. monocytogenes in this food product when post-contamination occurs (Stollewerk, Jofre, Comaposada, Arnau, \& Garriga, 2012). Thus, incoming products (including the exterior of their packages) that have been contaminated at food processing facilities pose a risk for cross-contamination of foods in the (hospital) food service operation when these incoming foods are opened and/or handled in the food service operation (Lianou \& Sofos, 2007). Therefore higher demands, such as well controlled storage conditions, well separated storage facilities and a forward flow allowing no crossing among raw materials, RTE meals and trash, are posed on the food safety management system in the food service operation. It can be noticed that the raw materials such as the raw salmon and the poultry meat, which were tested positive for $L$. monocytogenes, were not contaminated anymore after heat processing. L. monocytogenes is considered to be intolerant to the temperatures achieved during food processing, such as cooking and pasteurization (Kells \& Gilmour, 2004). Thus, the intervention processes applied in the food service operation are effective to inactivate the initial contamination. Therefore contamination of RTE foods (including hospital meals) with $L$. monocytogenes is almost exclusively due to post-processing contamination at the producers company and these foods, together with non-processed foods, are therefore more likely to be associated with listeriosis outbreaks than others (Hoelzer et al., 2011; Lianou \& Sofos, 2007). One hospital meal has been found positive for L. monocytogenes. This meal, called Ardennes egg, contained salt-free cooked ham, which was already contaminated as incoming RTE food product. Contamination, which had taken place at the manufacturer operation, could not be reduced because no heating step in the food service operation could be applied for this meal type. The positive incoming (raw) materials, raised the awareness that cross-contamination is possible and extra attention should be paid to the slicing machine to cut slices from the cooked meat. The same slicing equipment is used for normal cooked ham and salt-free cooked ham and no cleaning and disinfection step is currently present between the use of these different types of cooked meat, increasing the risk of crosscontamination (Lianou \& Sofos, 2007). It also suggests that incoming (raw) material control of suppliers, including the usual suppliers, should be performed on a regular base. From this case study it became also apparent that high-risk foods are still served in hospital food service operations, even though these high risk foods are not directly served to the patients but rather indirectly by offering them in the hospital canteen. However, the types of food served should be selected to minimize the risk of foodborne disease in patient (Lund \& O'Brien, 2009; Rodriguez et al., 2011). This means that high risk foods should not be served in the canteen. An operator willing to take such decisions and providing guidelines for a menu builder to reduce the risk of $L$. monocytogenes, would also contribute to a positive food safety culture (Powell et al., 2011). No complaints concerning food safety or hygiene and having no nonconformities with regard to food hygiene and food pathogens cannot guarantee that foodborne illness will be prevented. Especially if the food service operation relies only on guidance or oversight by government or auditors to ensure consumers receive safe food products. A food service operation should be more proactive by evaluating their food safety management system on a regular basis and performing product analyses, because the risk of a food service operation to cause foodborne illnesses is to a large extent, a consequence of its own activities (Powell et al., 2011) Therefore, effective food safety systems and practices need to be shared by all levels of the organization, not just management, and communication should be an integral part (Neal et al., 2012). Moreover, by analyzing the risks associated with their products and to know how to manage these risks, a more positive food safety culture can be established. Powell et al. (2011) concluded that the best food producers should go above and beyond minimal government and auditor standards.

\section{Conclusion}

The use of a (self-)assessment questionnaire to evaluate the current food safety management system performance and the implementation of a risk based sampling plan to verify the implemented control measures toward the presence of $L$. monocytogenes in a hospital service setting, are useful tools for a food service operation to gain more insight into and to adjust their own food management system. The risk based sampling plan helps to set priorities in selecting incoming materials and defining critical sampling locations to detect $L$. monocytogenes in the environment. By the application of both tools, an overview is obtained on the performance levels of the current implemented control and assurance activities and the results can be used as an internal audit to improve their system. From this case study, it becomes clear that incoming (raw) materials, produced final products and their immediate supply to patients/consumers are high risk situations. This was demonstrated by the presence of $L$. monocytogenes in incoming (raw) materials and final product. These risky situations are in need to be mitigated by the implementation of proper control measures, e.g. intensified supplier control, low storage temperatures, cleaning and disinfection to control cross-contamination. However, in terms of assurance activities, such as setting up a sampling plan, validation and verification of their food safety management system, only a basic level was obtained. Therefore, the food service operation does not know how well they are performing and is not capable of self-evaluation. Besides, being more pro-active a food service operation should also work to a good food safety culture, with all levels of the organization involved.

\section{References}

Anonymous. (2003). Koninklijk Besluit van 14 november 2003 betreffende autocontrole, traceerbaarheid en meldingsplicht in de voedselketen. Available online http://www.favv.be/autocontrole-nl/wetgeving/_documents/2003-11-14_AR_ autocontrole.pdf.

Anonymous. (2004). Regulation (EC) No 852/2004 of the European Parliament and of the Council of 29 April 2004 on the hygiene of foodstuffs. Official Journal of the European Union, 139, 1-54. Available online http://www.fsai.ie/uploadedFiles/ Reg852 2004(6).pdf.

Cairns, B. J., \& Payne, R. J. H. (2009). Sudden increases in Listeriosis rates in England and Wales, 2001 and 2003. Emerging Infectious Diseases, 15, 465-468.

Carpentier, B., \& Cerf, O. (2011). Persistence of Listeria monocytogenes in food industry equipment and premises. International Journal of Food Microbiology, 145, 1-8.

Denny, J., \& McLauchlin, J. (2008). Human Listeria monocytogenes infections in Europe - an opportunity for improved European surveillance. Eurosurveillance, 13. Available online http://www.eurosurveillance.org/viewarticle.aspx? ArticleId $=8082$

Dierick, K., \& Botteldoorn, N. (2007). Annual Report on foodborne outbreaks and antimicrobial resistance in zoonotic agents in Belgium 2007. Scientific Institute of 
Public Health. Depotnummer: D/2007/2505/54. Available online http://bacterio. wiv-isp.be/reporting/reportspdf/VTI\%202006.pdf.

Dierick, K., Botteldoorn, N., Denayer, S., \& Naranjo, M. (2009). Annual Report on foodborne outbreaks and antimicrobial resistance in zoonotic agents in Belgium 2007. Scientific Institute of Public Health. Depotnummer: D/2008/2505/35. Available online http://bacterio.wiv-isp.be/reporting/reportspdf/tia-nl007.pdf.

Dimitrijevíc, M., Anderson, R. C., Karabasil, N., Pavlicevic, N., Jovanovic, S., Nedeljkovic-trailovic, J., et al. (2011). Environmental prevalence and persistence of Listeria monocytogenes in cold-smoked trout processing plants. Acta Veterinaria, $61,429-442$.

Dufour, C. (2011). Application of EC regulation no. 2073/2005 regarding Listeria monocytogenes in ready-to-eat foods in retail and catering sectors in Europe. Food Control, 22, 1491-1494.

European Food Safety Authority (EFSA) \& European Centre for disease prevention and control. (2006). The Community summary report on trends and sources of zoonoses, zoonotic agents, antimicrobial resistance and foodborne outbreaks in the European Union in 2005. EFSA Journal, 94, 1-288.

European Food Safety Authority (EFSA) \& European Centre for disease prevention and control. (2007). The Community summary report on trends and sources of zoonoses, zoonotic agents, antimicrobial resistance and foodborne outbreaks in the European Union in 2006. EFSA Journal, 130, 1-352.

European Food Safety Authority (EFSA) \& European Centre for disease prevention and control. (2009). The Community summary report on trends and sources of zoonoses and zoonotic agents in the European Union in 2007. EFSA Journal, 223,1-320.

European Food Safety Authority (EFSA) \& European Centre for disease prevention and control. (2010). The Community summary report on trends and sources of zoonoses, zoonotic agents and food-borne outbreaks in the European Union in 2008. EFSA Journal, 8. http://dx.doi.org/10.2903/j.efsa.2010.1496.

European Food Safety Authority (EFSA) \& European Centre for disease prevention and control. (2011). The European Union summary report on trends and sources of zoonoses, zoonotic agents and food-borne outbreaks in 2009. EFSA Journal, 9. http://dx.doi.org/10.2903/j.efsa.2011.2090.

European Food Safety Authority (EFSA) \& European Centre for disease prevention and control. (2012). The European Union summary report on trends and sources of zoonoses, zoonotic agents and food-borne outbreaks in 2010. EFSA Journal, 10. http://dx.doi.org/10.2903/j.efsa.2012.2597.

Food and Agriculture Organisation and World Health Organisation (FAO/WHO). (2004). Risk assessment of Listeria monocytogenes in ready-to-eat foods. In Microbiological risk assessment series 5. Retrieved 27.06.13 from http://www. who.int/foodsafety/publications/micro/mra_listeria/en/.

Federaal Agentschap voor de Veiligheid van de Voedselketen (FAVV). (2004). Activiteitenverslag 2003. Retrieved 26.06.12 from http://www.afsca.be/ jaarverslagen/_documents/AV_2003_s.pdf.

Federaal Agentschap voor de Veiligheid van de Voedselketen. (2006a). Gids voor de invoering van een autocontrolesysteem in de Horecasector (G-023), 23/08/2006.

Federaal Agentschap voor de Veiligheid van de Voedselketen (FAVV). (2006b). Activiteitenverslag 2005. Retrieved 26.06.12 from http://www.favv.be/ jaarverslagen/documents/AV 05 NI_S.pdf.

Federaal Agentschap voor de Veiligheid van de Voedselketen (FAVV). (2007). Activiteitenverslag 2006. Retrieved 26.06.12 from http://www.favv.be/ jaarverslagen/_documents/AV_2006_Nl_S_new.pdf.

Federaal Agentschap voor de Veiligheid van de Voedselketen (FAVV). (2008a), Autocontrolegids voor de sector van de grootkeukens en verzorginstellingen ( $G$ 025), 22/01/2008.

Federaal Agentschap voor de Veiligheid van de Voedselketen (FAVV). (2008b). Activiteitenverslag 2007. Retrieved 26.06.12 from http://www.afsca.be/home/ pub/_documents/2008-08-28_AV2007_v2_nl.pdf/.

Federaal Agentschap voor de Veiligheid van de Voedselketen (FAVV). (2009a). Activiteitenverslag 2008. Retrieved 26.06 .12 from http://www.favv.be/ jaarverslagen/_documents/2009-07-07_AV08_nl.pdf.

Federaal Agentschap voor de Veiligheid van de Voedselketen (FAVV). (2009b). VVI7: Inspecties infrastructuur, inrichting en hygiëne in de sectoren distributie, horeca en gemeenschapskeukens. Available on http://www.afsca.be/wetenschappelijkcomite/ barometer/voedselveiligheid/_documents/VVI7.pdf.

Gandhi, M., \& Chikindas, L. (2007). Listeria: a foodborne pathogen that knows how to survive. International Journal of Food Microbiology, 113, 1-15.

Gillespie, I. A., McLauchlin, J., Grant, K. A., Little, C. L., Mithani, V., Penman, C., et al. (2006). Changing pattern of human listeriosis, England and Wales, 2001-2004. Emerging Infectious Diseases, 12, 1361-1366.

Gillespie, I. A., Mook, P., Little, C. L., Grant, K. A., \& Adak, G. K. (2010). Listeria monocytogenes infection in the over-60s in England between 2005-2008: a retrospective case-control study utilizing market research panel data. Foodborne Pathogens and Disease, 7, 1373-1379.

Goulet, V., Hedberg, C., Le Monnier, A., \& de Valk, H. (2008). Increasing incidence of listeriosis in France and other European countries. Emerging Infectious Diseases, $14,734-740$.

Green, L. R., Selman, C. A., Radke, V., Ripley, D., Mack, J. C., Reimann, D. W., et al. (2006). Food worker hand washing practices: an observation study. Journal of Food Protection, 69, 2417-2423.

Hedin, G., Rynbäck, J., \& Loré, B. (2010). New technique to take samples from environmental surfaces using flocked nylon swabs. Journal of Hospital Infection, 75, 314-317.

Hoelzer, K., Sauders, B. D., Sanchez, M. D., Olsen, P. T., Pickett, M. M., Mangione, K. J., et al. (2011). Prevalence, distribution, and diversity of Listeria monocytogenes in retail environments, focusing on small establishments and establishments with a history of failed inspections. Journal of Food Protection, 74, 1083-1095.
International Commission on Microbiological Specifications for foods (ICMSF) (1986). Microorganisms in food 2: Sampling for microbiological analysis: Principles and specific applications. Toronto: University of Toronto Press. ISBN 0802056938.

International Commission on Microbiological Specifications for foods (ICMSF) (2002). Microorganisms in food 7: Microbiological testing in food safety management (1st ed.). New York: Kluwer Academic/Plenum Publishers. ISBN 030642627.

International Commission on Microbiological Specifications for foods (ICMSF) (2005). Microorganisms in food 6. Mircobial ecology of food commodities (2nd ed.). New York: Kluwer Academic/Plenum Publishers. ISBN 030648675.

Jacxsens, L., Uyttendaele, M., Devlieghere, F., Rovira, J., Osés Gomez, S., \& Luning, P. A. (2010). Food safety performance indicators to benchmark food safety output of food safety management systems. International Journal of Food Microbiology, 141, 180-187.

Jacxsens, L., Luning, P. A., Marcelis, W. J., van Boekel, T., Rovira, J., Oses, S., et al (2011). Tools for the performance assessment and improvement of food safety management systems. Trends in Food Science E Technology, 22, S80-S89.

Jones, T. F., \& Angulo, F. J. (2006). Eating in restaurants: a risk factor for foodborne disease? Clinical Infectious Diseases, 43, 1324-1328.

Jones, S. L., Parry, S. M., O’Brien, S. J., \& Palmer, S. R. (2008). Operational practices associated with foodborne disease outbreaks in the catering industry in England and Wales. Journal of Food Protection, 71, 1659-1665.

Kells, J., \& Gilmour, A. (2004). Incidence of Listeria monocytogenes in two milk processing environments, and assessment of Listeria monocytogenes blood agar for isolation. International Journal of Food Microbiology, 91, 167-174.

Lahou, E., Jacxsens, L., Daelman, J., Van Landeghem, F., \& Uyttendaele, M. (2012) Microbiological performance of a food safety management system in a food service operation. Journal of Food Protection, 75, 706-716.

Lianou, A., \& Sofos, J. N. (2007). A review of the incidence and transmission of Listeria monocytogenes in ready-to-eat products in retail and food service environments. Journal of Food Protection, 70, 2172-2198.

Lund, B. M., \& O'Brien, S. J. (2009). Microbiological safety of food in hospitals and other healthcare settings. Journal of Hospital Infection, 73, 109-120.

Luning, P. A., Bango, L., Kussaga, J., Rovira, J., \& Marcelis, W. J. (2008). Comprehensive analysis and differentiated assessment of food safety control systems: a diagnostic instrument. Trends in Food Science E Technology, 19, 522-534.

Luning, P. A., Marcelis, W. J., Rovira, J., Van der Spiegel, M., Uyttendaele, M., \& Jacxsens, L. (2009). Systematic assessment of core assurance activities in a company specific food safety management system. Trends in Food Science \& Technology, 20, 300-312.

Luning, P. A., Marcelis, W. J., Rovira, J., Van Boekel, M. A. J. S., Uyttendaele, M., \& Jacxsens, L. (2011). A tool to diagnose context riskiness in view of food safety activities and microbiological safety output. Trends in Food Science E Technology 22, S67-S79.

Luning, P. A., Jacxsens, L., Rovira, J., Osés, S. M., Uyttendaele, M., \& Marcelis, W. J (2011). A concurrent diagnosis of microbiological food safety output and food safety management system performance: cases from meat processing industries. Food Control, 22, 555-565.

Metelmann, C., Schulz, K., Geldschläger-Canda, R., Plötz, S., \& Handrick, W. (2010) Listeriose bei erwachsenen - fallberichte und literature-übersicht. Wiener klinische Wochenschrift, 122, 354-359.

Moore, G., \& Griffith, C. (2007). Problems associated with traditional hygiene swabbing: the need for in-house standardization. Journal of Applied Microbiology, 103, 1090-1103.

Muñoz, P., Rojas, L., Bunsow, E., Saez, E., Sánchez-Cambronero, L., Alcalá, L., et al (2011). Listeriosis: an emerging public health problem especially among the elderly. Journal of Infection, 64, 19-33.

Neal, J. A., Binkley, M., \& Henroid, D. (2012). Assessing factors contributing to food safety culture in retail food establishments. Food Protection Trends, 32, 468-476.

Panisello, P. J., \& Quantick, P. C. (2001). Technical barriers to hazard analysis critical control point (HACCP). Food Control, 12, 165-173.

Powell, D. A., Jacob, C. J., \& Chapman, B. J. (2011). Enhancing food safety culture to reduce rates of foodborne illness. Food Control, 22, 817-822.

Rodriguez, M., Valero, A., Carrasco, E., Pérez-Rodríguez, F., Posada, G. D., \& Zurera, G. (2011). Hygienic conditions and microbiological status of chilled ready-to-eat products served in southern Spanish hospitals. Food Control, 22, 874-882.

Stollewerk, K., Jofre, A., Comaposada, J., Arnau, J., \& Garriga, M. (2012). The effect of $\mathrm{NaCl}$-free processing and high pressure on the fate of Listeria monocytogenes and Salmonella on sliced smoked dry-cured ham. Meat Science, 90, 472-477.

Tompkin, R. B. (2002). Control of Listeria monocytogenes in the food-processing environment. Journal of Food Protection, 65, 709-725.

Uyttendaele, M., Busschaert, P., Valero, A., Geeraerd, A. H., Vermeulen, A. Jacxsens, L., et al. (2009). Prevalence and challenge tests of Listeria monocytogenes in Belgian produced and retailed mayonnaise-based deli-salads, cooked meat products and smoked fish between 2005 and 2007. International Journal of Food Microbiology, 133, 94-104.

Uyttendaele, M., Jacxsens, L., De Loy-Hendrickx, A., Devlieghere, F., \& Debevere, J (2010). Microbiologische richtwaarden en wettelijke microbiologische criteria. Ghent, Belgium: Laboratory of Food Microbiology and Food Preservation, University of Ghent. ISBN: 978-90-5989-385-6.

Van Coillie, E., Werbrouck, H., Heyndrickx, M., Herman, L., \& Rijpens, N. (2004). Prevalence and typing of Listeria monocytogenes in ready-to-eat food products on the Belgian market. Journal of Food Protection, 67, 2480-2487.

Worsfold, D. (2001). A guide to HACCP and function catering. Journal of the Royal Society for the Promotion of Health, 121, 224-229. 